УДК 656.224

Т.О. Лінецька,

канд. техн. наук О.А. Малахова

\title{
УДОСКОНАЛЕННЯ ПЕРЕВЕЗЕННЯ ПАСАЖИРІВ ІЗ ЗАСТОСУВАННЯМ ЛОГІСТИЧНИХ ПІДХОДІВ
}

\author{
Представив д-р техн. наук, професор О.М. Огар
}

Пасажирські залізничні перевезення відіграють важливу соціальну і економічну роль у житті держави. Це обумовлено їх високим соціально-економічним значенням у виконанні однієї 3 найважливіших цивільних гарантій держави - забезпечення свободи пересування.

Пасажирським

залізничним перевезенням надавалося велике значення на кожному етапі розвитку нашої країн. Рівень пасажирських перевезень створює імідж транспорту в цілому, визначає ступінь реалізації потреби населення в перевезеннях, зміцнює впевненість в стабільності держави за рахунок підтримки соціально-доступних тарифів на послуги залізничного транспортного зв'язку. Зараз сфера пасажирських перевезень знаходиться на складному етапі, необхідно вирішувати проблеми адаптації до роботи в умовах жорсткої конкуренції з боку інших видів транспорту, для чого потрібно розвивати та удосконалювати ринок транспортних послуг.

Пасажирські перевезення залізничним транспортом на сьогодні збиткові. Однією 3 причин збитковості $€$ невідповідність темпів зростання цін на продукцію та ресурси (металопрокат, залізобетонні шпали, запасні частини для рухомого складу, дизельне пальне та електроенергія тощо) i темпів підвищення тарифів на пасажирські перевезення.

Тарифи на залізничні перевезення жорстко регулюються державою, а ціни на продукцію, що необхідна залізницям, формуються в ринкових умовах. Лише за останні роки ціни зросли так: на металопрокат - до $117,1 \%$, катанку - на $103,8 \%$, залізобетонні шпали - до $54 \%$, локомотивні бандажі - на $32,1 \%$, суцільнокатані колеса 3 підвищеною 
твердістю - на 36,6 \%, запасні частини для рухомого складу - до $178,1 \%$.

Разом 3 тим підвищилася вартість рухомого складу вітчизняного виробництва, зокрема пасажирських електровозів постійного струму - на $13 \%$, електровози змінного струму - на $10 \%$. Паралельно зросли ціни і на енергоносії: природного газу - на 56,1 \%, електроенергії - на $41,5 \%$, а дизельного палива - на $15,8 \%$. Все це призводить до збільшення запланованих витрат на перевезення пасажирів.

Тому для повернення прихильності споживачів послуг залізниці насамперед необхідно покращити обслуговування пасажирів за допомогою застосування принципів пасажирської логістики. Розробкою та застосуванням принципів пасажирської логістики на транспорті займалися такі вітчизняні та закордонні вчені: А.У. Альбеков, Б.А. Анікін, Д. Бауерсокс, Г.Л. Багієв, Т.В. Бутько, А.М. Гаджинський,

В.Д. Герамі, О.В. Гудков, М.І. Данько, В.В. Дибська, Д. Клосс, А.В. Прохорченко та ін.

Стосовно пасажирського транспорту логістика являє собою сукупність проектних рішень, технічних засобів i методів організації та управління, які забезпечують заданий рівень обслуговування пасажирів, їх безпечну, надійну i безперервну доставку в певний час при мінімальних витратах [1]. Застосування логістики на пасажирському транспорті дозволяє оптимізувати перевізний процес, розглянутий як логістична система операторів та об'єктів інфраструктури, за допомогою логістичних зв'язків, що беруть участь в процесі надання транспортних послуг.

Однією 3 цілей логістики $\epsilon$ задоволення попиту споживачів шляхом оптимізації людських і матеріальних потоків за допомогою організації інформаційних потоків на основі системного підходу [2].
Системний підхід - концептуальна основа логістики, що включає теорію систем, проектування i структурування системи з метою оптимізації використання просторових i часових ресурсів, організацію людських, матеріальних, фінансових та інформаційних потоків.

Відправною точкою при організації логістичних систем $є$ орієнтація системи на матеріальні потоки, об'єднані ланцюгом логістичних операцій при слідуванні на всьому маршруту прямування. У зв'язку 3 цим одним 3 найважливіших завдань $€$ оптимізація матеріальних потоків, підвищення їх швидкості при збереженні на відповідному рівні всіх параметрів i підвищення економічної ефективності процесів, що обслуговуються.

Матеріальний потік у пасажирській транспортній логістиці - кількість пасажирів, що розглядаються в процесі різних транспортних логістичних операцій і віднесені до певного часового інтервалу. Одиницею виміру матеріального потоку служить відношення кількості пасажирів до розмірності тимчасового інтервалу (доба, місяць, рік і т.д.), тобто інтенсивність пасажиропотоку.

Особливістю ланок логістичної системи громадського транспорту $\epsilon$ перетворення матеріального потоку на вході в сервісний потік на виході.

Сервісний потік являє собою пасажирські послуги, надані підприємствами громадського транспорту пасажирам для їх переміщення в часі $\mathrm{i}$ просторі. Цей потік в логістичній системі громадського транспорту характеризують такі чинники:

- умови обслуговування різних соціальних груп населення;

- витрати часу на пересування; засобів;

- регулярність руху транспортних

- комфортабельність проїзду;

- величина транспортного тарифу та ін. 
Незважаючи на важливість транспортного сервісу, досі відсутні ефективні способи оцінки його якості. Це пояснюється відсутністю чітких характеристик особливостей пасажирського сервісу.

Для міських та приміських пасажирських перевезень характерним є те, що інтереси пасажира i перевізника не збігаються [3]. Одна 3 суперечностей їхніх інтересів полягає в тому, що перевізник зацікавлений у збільшенні виручки, в тому числі і за рахунок збільшення коефіцієнта змінності та використання місткості, а пасажир - у безпересадочній та швидкій доставці до місця призначення за мінімальний тариф.

3 точки зору пасажира, ефективність міських пасажирських перевезень визначається надійністю обслуговування, комфортом поїздки і доступністю тарифу.

Проблема пошуку компромісу виявляється i у виборі транспортного засобу та маршруту пересування.

Порівняння i вибір транспортних засобів являє собою багатокритеріальну задачу. Основними показниками, що впливають на вибір рухомого складу, є: місткість транспортного засобу, тяговошвидкісні якості, зручність користування для пасажирів, безпека (активна, пасивна, післяаварійна), екологічність транспортного засобу.

Для вирішення питання перевезення пасажирів в логістичній транспортній системі доцільно застосування теорії матричних ігор. Суть теорії ігор полягає у формулюванні i доведенні умов, які забезпечують оптимальне рішення у разі взаємодії декількох учасників, що мають незбіжні інтереси. Сторони, які беруть участь, є гравцями, а процес їх взаємодії грою. Розбіжність інтересів може виражатися різним чином, аж до антагонізму. Разом 3 тим теорія ігор показала, що повного антагонізму інтересів принципово не існує. Завжди можуть бути виділені області, в яких відзначається збіг інтересів навіть протиборчих сторін.

Кожна сторона в процесі взаємодії намагається поліпшити своє становище, або, інакше кажучи, $i$-й гравець прагне до збільшення свого виграшу, описуваного критерієм $W_{i}$. Спосіб дій, реалізований гравцем, представляє його стратегію i полягає у виборі деяких параметрів $x_{i} \in X_{i}$.

Теореми теорії ігор математично доводять можливість пошуку узгодженого оптимуму для сторін-учасниць і додаються до широкого кола завдань, що допускають теоретико-ігрову інтерпретацію.

Взаємодія двох операторів транспортного ринку може бути описана на основі моделі ринкової конкуренції $[4(1,5)]$ :

$$
\begin{aligned}
& w_{i}=\left\{\begin{array}{c}
(q-b) \text { х при } q \leq p \\
\min [C-p x, q y]-\text { yb при } q=p
\end{array} ;\right. \\
& w_{i}=\left\{\begin{array}{c}
(p-a) \text { x npu } p \leq q \\
\min [C-q y, p x]-\text { ax } n p u p=q
\end{array},\right.
\end{aligned}
$$

де $p$ - ціна на послуги першого оператораперевізника, грн;

$a$ - собівартість послуг першого оператора-перевізника, грн;

$x$ - обсяг послуг першого оператораперевізника, од.;

$q$ - ціна на послуги другого оператораперевізника, грн;

$b \quad$ - собівартість послуг другого оператора - перевізника, грн;

$y$ - обсяг послуг другого оператораперевізника, од.;

$C$ - величина платоспроможного попиту споживачів транспортних послуг.

У моделі діють обмеження

$$
0 \leq x \leq K, 0 \leq y \leq L, 0 \leq p \leq t, 0 \leq q \leq t
$$


де $K i L$ - провізні спроможності першого і другого операторів, од/доб;

$t$ - гранична величина тарифу на послуги, грн.

Важливим елементом прийняття рішення $\epsilon$ вибір критерію. Теорія ігор показала, що не існує єдиного поняття оптимуму.

Розглянемо на прикладі вибір транспортного засобу пасажиром, який прямує із міста в приміському сполученні. Під стратегією «А» розуміємо вибір пасажиром виду транспорту (автомобільний або залізничний), під стратегією «В» - набір послуг, що надаються перевізником в транспортних засобах різних категорій.

Матрична гра задана наступною платіжною матрицею (табл. 1).

Початкова платіжна матриця

\begin{tabular}{||c||c|c|c||}
\hline & \multicolumn{3}{|c|}{ Стратегї «B» } \\
\hline \hline Стратегіï «A» & $\mathrm{B}_{1}$ & $\mathrm{~B}_{2}$ & $\mathrm{~B}_{3}$ \\
\hline $\mathrm{A}_{1}$ & 3245.15 & 3251.44 & 1353.69 \\
\hline $\mathrm{A}_{2}$ & 4213.25 & 2987.01 & 2543.46 \\
\hline
\end{tabular}

Таблиця 1

Знайти рішення матричної гри, а саме:

- знайти верхню ціну гри;

- нижню ціну гри;

- чисту ціну гри;

- вказати оптимальні стратегії гравців.

Крок 1. Визначимо нижню ціну гри $\alpha$.

Нижня ціна гри $\alpha$ - це максимальний виграш, який ми можемо гарантувати собі, якщо протягом всієї гри будемо використовувати одну i тільки одну стратегію (така стратегія називається "чистою").

Знайдемо в кожному рядку платіжної матриці мінімальний елемент i запишемо його в додатковий стовпець. Потім знайдемо максимальний елемент додаткового стовпця, це і буде нижня ціна гри (табл. 2).

У нашому випадку нижня ціна гри дорівнює: $\alpha=2543.46$, і для того щоб гарантувати собі виграш не гірше ніж 2543.46, ми повинні дотримуватися стратегії А2.

Таблиця 2

Знаходження нижньої ціни гри платіжної матриці

\begin{tabular}{||c||c|c|c||c||}
\hline \multicolumn{1}{|c||}{} & \multicolumn{3}{c||}{ Стратегіï «В» } & \\
\hline \hline Стратегіï «A» & $\mathrm{B}_{1}$ & $\mathrm{~B}_{2}$ & $\mathrm{~B}_{3}$ & Мінімуми рядків \\
\hline \hline $\mathrm{A}_{1}$ & 3245.15 & 3251.44 & 1353.69 & 1353.69 \\
\hline $\mathrm{A}_{2}$ & 4213.25 & 2987.01 & 2543.46 & $\mathbf{2 5 4 3 . 4 6}^{*}$ \\
\hline \hline
\end{tabular}


Крок 2. Визначимо верхню ціну гри $\beta$

Верхня ціна гри $\beta$ - це мінімальний програш, який може гарантувати собі гравець «В», якщо протягом всієї гри він буде використовувати одну і тільки одну стратегію.
Знайдемо в кожному стовпці платіжної матриці максимальний елемент і запишемо його в додатковий рядок знизу (табл. 3). Потім знайдемо мінімальний елемент додаткового рядка, це i буде верхня ціна гри.

Знаходження верхньої ціни гри платіжній матриці

Таблиця 3

\begin{tabular}{||c||c|c|c|c||}
\hline \multicolumn{1}{|c||}{} & \multicolumn{3}{c|}{ Стратегії «B» } & \\
\hline \hline Стратегії «А» & $\mathrm{B}_{1}$ & $\mathrm{~B}_{2}$ & $\mathrm{~B}_{3}$ & Мінімуми рядків \\
\hline \hline $\mathrm{A}_{1}$ & 3245.15 & 3251.44 & 1353.69 & 1353.69 \\
\hline \hline $\mathrm{A}_{2}$ & 4213.25 & 2987.01 & 2543.46 & $\mathbf{2 5 4 3 . 4 6}^{*}$ \\
\hline \hline Максимуми стовпџів & 4213.25 & 3251.44 & $\mathbf{2 5 4 3 . 4 6}^{+}$ & \\
\hline \hline
\end{tabular}

У нашому випадку верхня ціна гри дорівнює: $\beta=2543.46$, і для того щоб гарантувати собі програш не гірше ніж 2543.46, супротивник (гравець "В") повинен дотримуватися стратегії В3.

Крок 3. Порівняємо нижню і верхню ціни гри, в даній задачі вони збігаються, тобто $\alpha=\beta=2543.46$. Це означає, що гра має рішення в так званих "чистих", мінімаксних стратегіях. Це якраз ті стратегії для гравців «А» $\mathrm{i}$ «В», які були знайдені вище, при пошуку нижньої i верхньої цін гри. Тобто в нашому випадку для гравця «А» оптимальною буде стратегія А2, а для гравця «В»- В3.

Неважко помітити, що елемент платіжної матриці розташований на пере- тині чистих оптимальних стратегій (рядок 2, стовпець 3), є одночасно мінімальним у рядку й максимальним у стовпці (відзначений знаками * + у табл. 3). Такі елементи називаються сідловими точками, саме їх наявність i визначає існування рішення гри в чистих стратегіях, a його значення (y нашому випадку 2543.46) збігається 3 чистою ціною гри або просто ціною гри $-v$.

Пара оптимальних стратегій, які в іграх мають сідлову точку, завжди проходить через неї (табл. 4).

Нижня ціна гри, верхня ціна гри i чиста ціна гри: $\alpha=\beta=v=2543.46$, а пара оптимальних стратегій $-\boldsymbol{A 2 B 3 .}$

Визначення сідлової точки

\begin{tabular}{||c|c|c|c||c||}
\hline \multicolumn{1}{|c|}{} & \multicolumn{3}{|c||}{ Стратегія "B" } & \\
\hline \hline Стратегія "A" & $\mathrm{B}_{1}$ & $\mathrm{~B}_{2}$ & $\mathrm{~B}_{3}$ & Мінімуми рядків \\
\hline \hline $\mathrm{A}_{1}$ & 3245.15 & 3251.44 & 1353.69 & 1353.69 \\
\hline $\mathrm{A}_{2}$ & 4213.25 & 2987.01 & $\mathbf{2 5 4 3 . 4 6}^{*+}$ & $\mathbf{2 5 4 3 . 4 6}^{*}$ \\
\hline
\end{tabular}


Висновок. Порівняння i вибір транспортних засобів для перевезення пасажирів у приміському та міському сполученнях являє собою багатокритеріальну задачу. Для вирішення питання перевезення пасажирів в логістичній транспортній системі запропоновано застосовувати теорію матричних ігор. Теореми теорії ігор математично доводять можливість пошуку узгодженого оптимуму для сторінучасниць. Розрахунки для двох видів транспорту (автомобільного та залізничного) при їх взаємодії за технологією єдиного проїзного документа дають більш раціональний варіант пересування пасажирів, ніж суто автомобільний та індивідуальний.

\section{Список літератури}

1. Артынов, А.Л. Автоматизация процессов планирования и управления транспортными системами [Текст] / А.Л. Артынов, В.В. Скалецкий. - М.: Наука, 1981. - 522 с.

2. Бауерсокс, Д. Логістика: інтегрований ланцюг поставок [Текст]: пер. 3 англ. ЗАТ «Олімп-Бізнес». - К.: Рад. шк., 2006. - 306 с.

3. Гудков, В.О. Технология, организация и управление пассажирскими автомобильными перевозками [Текст]: учеб. для вузов / В.О. Гудков, Л.Б. Миротин / под ред. Л.Б. Миротина. - М.: Транспорт, 1997. - 665 с.

4. Вельможин, А.В. Теория транспортных процессов и систем [Текст] / А.В. Вельможин, В.О. Гудков, Л.Б. Миротин. - М.: Транспорт, 1998. -276 с.

Ключові слова: пасажирські перевезення, пасажирська логістика, сервісний потік, теорія матричних ігор.

\section{Анотації}

Покращення обслуговування пасажирів за допомогою застосування принципів пасажирської логістики дозволить привернути увагу частини учасників пасажиропотоку, які користуються іншими видами транспорту, зокрема автомобільним. Основною метою залізниць є задоволення попиту споживачів шляхом оптимізації людських і матеріальних потоків за допомогою організації інформаційних потоків на основі системного підходу.

Запропоновано для вирішення питання перевезення пасажирів у логістичній транспортній системі при користуванні різними видами транспорту застосовувати теорію матричних ігор.

Улучшение обслуживания пассажиров посредством применения принципов пассажирской логистики позволит привлечь внимание части участников пассажиропотока, пользующихся другими видами транспорта, в частности автомобильным. Основной целью железных дорог является удовлетворение спроса потребителей путем оптимизации людских и материальных потоков посредством организации информационных потоков на основе системного подхода.

Предложено для решения вопроса перевозки пассажиров в логистической транспортной системе при использовании различных видов транспорта применять теорию матричных игр.

Improvement of passenger service by applying the principles of passenger logistics will attract the attention of the passenger who use other modes of transport, in particular road. The main 
purpose of the railways is to meet consumer demand by optimizing the human and material flows through the organization of information flows in a systematic manner.

Proposed solutions for the transport of passengers in the logistics of the transport system by using different modes of transport to apply the theory of matrix games. 